\title{
Action of growth hormone in vitro on the net uptake and incorporation into protein of amino acids in muscle from intact rabbits given protein-deficient diets
}

\author{
By M. R. TURNER, P. J. REEDS AND K. A. MUNDAY \\ Department of Physiology and Biochemistry, The University, \\ Southampton $\mathrm{SO}_{3} \mathrm{TU}$
}

(Received 29 Fuly 1974-Accepted I I December 1974)

\begin{abstract}
I. Net amino acid uptake, and incorporation into protein have been measured in vitro in the presence and absence of porcine growth hormone (GH) in muscle from intact rabbits fed for $5 \mathrm{~d}$ on low-protein (LP), protein-free (PF) or control diets.

2. In muscle from control and LP animals GH had no effect on the net amino acid uptake but stimulated amino acid incorporation into protein, although this response was less in LP animals than in control animals.

3. In muscle from PF animals, GH stimulated both amino acid incorporation into protein and the net amino acid uptake, a type of response which also occurs in hypophysectomized animals. The magnitude of the effect of $\mathrm{GH}$ on the incorporation of amino acids into protein was reduced in muscle from PF animals.

4. The effect of GH on the net amino acid uptake in PF animals was completely blocked by cycloheximide; the uptake effect of $\mathrm{GH}$ in these animals was dependent therefore on de novo protein synthesis.

5. It is proposed that in the adult the role of growth hormone in protein metabolism is to sustain cellular protein synthesis when there is a decrease in the level of substrate amino acids, similar to that which occurs during a short-term fast or when the dietary protein intake is inadequate.
\end{abstract}

Protein synthesis is impaired in muscle from hypophysectomized animals, and is stimulated by the administration of growth hormone (GH) in vivo, or by including GH in the incubation medium in vitro (Kostyo \& Knobil, r959; Manchester \& Young, 196I). In muscle from hypophysectomized animals, GH also stimulates the uptake of some amino acids (Knobil, I966) an effect which is blocked by the inhibitors of protein synthesis puromycin and cycloheximide, but not by actinomycin D (Hjalmarson, I968; Kostyo, 1968; Kostyo \& Rillema, 1971). More recently it has been found that $\mathrm{GH}$ can stimulate the incorporation into protein of the amino acids leucine, valine, arginine, lysine and histidine in muscle from intact rabbits in vitro, without having any effect on amino acid uptake (Reeds, Munday \& Turner, 1971). A similar finding is reported for leucine incorporation into protein in rat liver incubated in vitro with high concentrations of a complete amino acid mixture such as may be found in portal plasma (Clemens \& Korner, 1970).

When the dietary protein intake is reduced, there is an increase in the circulating levels of GH in human infants (Pimstone, Barbezat, Hansen \& Murray, I968; Milner, 1971) and in rabbits (Turner, Allen \& Munday, I974) but a severe restriction of both protein and energy intake early in life may result in reduced plasma GH levels (Beas, Contreras, Maccioni \& Arenas, 197r). The rate of growth in malnourished infants does not usually relate to circulating levels of $\mathrm{GH}$, and it has been 
suggested that there may be diet-induced changes in the tissue responses to hormones in the malnourished (Turner, 1972). In the work described in this paper, the effectiveness of GH in stimulating amino acid uptake, and incorporation into protein in vitro, has been measured in muscle from intact rabbits given low-protein (LP) or proteinfree (PF) diets for $5 \mathrm{~d}$. A preliminary report of part of this work has been published (Turner, Reeds \& Munday, r971).

\section{EXPERIMENTAL}

\section{Animals and diets}

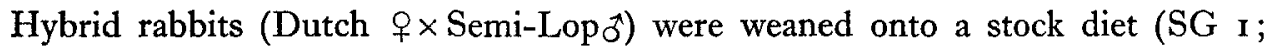
Rank Hovis MacDougall Ltd, Southampton) which supplied about $200 \mathrm{~g}$ protein $/ \mathrm{kg}$ dry weight, and were used for experiment at approximately $3 \mathrm{~kg}$ body-weight. Rabbits were allocated to control and test groups on the basis of weight, sex and litter so that there were two males and three females or three males and two females in each group, the mean weight of each group was similar, and the variation in bodyweight of individual animals within groups was minimal. Rabbits were given, for $5 \mathrm{~d}$, an LP diet ( $5 \circ \mathrm{g}$ casein $/ \mathrm{kg}$ ) or a PF (protein-free) diet or continued to receive the stock diet. The experimental diets contained ( $\mathrm{g} / \mathrm{kg}$ dry weight): maize oil 100 , sucrose $\mathrm{r}_{50} \mathrm{O}$, cellulose 300 , salt mixture 40 , vitamin mixture ro and either maize starch 340 plus casein $50(\mathrm{LP})$, or maize starch $39 \circ(\mathrm{PF})$. The salt mixture was that of Jones \& Foster (I942) and the vitamin mixture was of the following composition (/kg): biotin $39 \mathrm{mg}$, cyanocobalamin $10 \mathrm{mg}$, pteroylmonoglutamic acid $390 \mathrm{mg}$, myo-inositol $3.9 \mathrm{~g}$, nicotinic acid $9.75 \mathrm{~g}$, calcium pantothenate $\mathrm{Ir} \cdot 6 \mathrm{~g}$, pyridoxine hydrochloride $390 \mathrm{mg}$, riboflavin $1.93 \mathrm{~g}$, thiamin hydrochloride $580 \mathrm{mg}$, choline hydrochloride Iro $\mathrm{g}$, $p$-aminobenzoic acid r ro g, Rovimix A+D (Roche Products Ltd, Welwyn Garden City, Herts.; supplying $98 \mathrm{mg}$ retinol and $2.03 \mathrm{mg}$ cholecalciferol $/ \mathrm{g}$ ) $50 \mathrm{~g}$, Rovimix E (Roche Products Ltd; supplying I70 mg $\alpha$-tocopherol equivalent/g) $50 \mathrm{~g}$, menaphthone $2 \cdot 0 \mathrm{~g}$, and maize starch to I $\mathrm{kg}$.

Results from the animals given experimental diets were compared with those from animals given the stock diet throughout.

\section{Methods}

Amino acid uptake and incorporation. Amino acid uptake and incorporation was measured in diaphragm muscle pieces in vitro, in the presence or absence of porcine GH (Lot P 522A, potency 2 I.U./mg; a kind gift from Dr A. E. Wilhelmi, National Institutes of Health, Bethesda, Md., USA) using materials and methods described in full elsewhere (Reeds et al. 1971). Animals were killed by cervical fracture at 10.30 hours, after a $3 \mathbf{h}$ fast which followed normal overnight feeding activities. Muscle was incubated at $37^{\circ}$ for $\mathrm{r} \mathrm{h}$ in a Krebs bicarbonate buffer, $\mathrm{pH} 7 \cdot 4$, containing $2 \mathrm{mg}$ glucose $/ \mathrm{ml}, \quad 0.16 \mathrm{mmol}\left[{ }^{3} \mathrm{H}\right]$ leucine, $0.18 \mathrm{mmol}\left[{ }^{3} \mathrm{H}\right]$ lysine, $0.15 \mathrm{mmol}$ $\left[{ }^{3} \mathrm{H}\right]$ arginine, $0.05 \mathrm{mmol}\left[{ }^{3} \mathrm{H}\right]$ histidine, $0.12 \mathrm{mmol}\left[{ }^{14} \mathrm{C}\right]$ valine (all with specific radioactivity $0.2 \mu \mathrm{Ci} / \mu \mathrm{mol}$ ), with or without $0.5 \mu \mathrm{g} \mathrm{GH} / \mathrm{ml}$. This dose of $\mathrm{GH}$ is about 
Table I. Total and extracellular water content of diaphragm muscle from intact rabbits fed for $5 d$ on low-protein $(L P)$, protein-free $(P F)$ or control diets $\uparrow$

(Mean values with their standard errors for six determinations/group)

\begin{tabular}{|c|c|c|c|}
\hline & Control & LP & PF \\
\hline $\begin{array}{c}\text { Total tissue water } f \\
(\mu \mathrm{l} / \mathrm{g} \text { fresh tissue })\end{array}$ & $665 \pm I 4$ & $686 \pm 40$ & $73 \circ \pm 12^{* * *}$ \\
\hline $\begin{array}{c}\text { Extracellular water } f \\
\text { ( } \mu \mathrm{l} / \mathrm{g} \text { fresh tissue) }\end{array}$ & $225 \pm 08$ & 2 I $5 \pm$ II & $189 \pm 10^{*}$ \\
\hline
\end{tabular}

fifty times a normal physiological concentration, but is considered justified for use in an in vitro system.

After incubation, amino acids in the medium, in the total tissue fluid, and in tissue protein hydrolysates were separated by thin-layer chromatography, and the amount of radioactivity in the labelled amino acids was measured using a scintillation procedure (Reeds et al. 1971).

The uptake of free amino acid was expressed in terms of the intracellular fluid volume, calculated from determinations of the extracellular space (see below) and the total tissue water, assuming a uniform specific activity of amino acid in the extracellular and intracellular fluid compartments. Although this assumption may be challenged, it was considered preferable to make a correction for the extracellular fluid volume, which varied between dietary groups independently of the total tissue water (Table I), than to express the results merely in terms of the total tissue water.

Total and extracellular water. The total tissue water was determined by oven drying at $105^{\circ}$ for $4 \mathrm{~h}$. Extracellular fluid volume was determined by a sucrose method (Hjalmarson, 1968). Pieces of diaphragm muscle were incubated for $\mathrm{I} h$ at $37^{\circ}$ in a Krebs bicarbonate buffer, $\mathrm{pH} 7 \cdot 4$, containing $2 \mathrm{mg}$ glucose $/ \mathrm{ml}$ and $\left[\mathrm{U}-{ }^{14} \mathrm{C}\right]$ sucrose (specific radioactivity $0^{\circ} \mathrm{I} \mu \mathrm{Ci} / \mathrm{ml}$ ). After incubation the amount of radioactivity in the medium and in the total tissue fluid were measured using the scintillation procedure mentioned previously, and the extracellular fluid volume was obtained by calculation. Intracellular fluid volume was obtained by difference.

\section{RESULTS}

Feeding rabbits for $5 \mathrm{~d}$ on either the PF or LP diet had little effect on food consumption or body-weight. Food intakes ( $\mathrm{g} / \mathrm{kg}$ body-weight per d) were: control 28 , LP 27, PF 30; weight changes (g/rabbit per d) were: control o, LP - Io, PF - 20 . However, there were changes in the amount and distribution of water in the muscle (Table I). In the PF group, the total water content was increased by ro\% whereas the extracellular fluid volume was reduced by $12 \%$; both changes were statistically significant. No such changes were found in the LP group.

There was no significant change in the basal net uptake of leucine in either the LP 
Table 2. Basal net uptake of amino acids (nmol/h per $g$ fresh muscle) by diaphragm muscle† from intact rabbits fed for 5 d on low-protein $(L P)$, protein-free $(P F)$ or control diets $\uparrow$

(Mean values with their standard errors for five determinations/group)

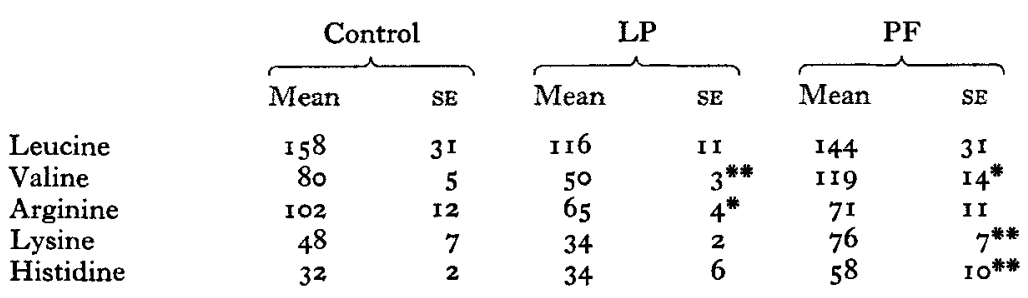

Statistical significance of difference from control value: ${ }^{*} P<0.05$, * $P<0.01$.

$\uparrow$ For details of incubation procedure, see p. 2.

For details of diets, see p. 2.

Table 3. Effect of growth hormone $(G H)(0.5 \mu g / m l)$ on the net uptake (relative to the basal uptake) of amino acids (nmol/h per g fresh muscle) by diaphragm muscle $\ddagger$ from intact rabbits fed for 5 d on low-protein $(L P)$, protein-free $(P F)$ or control diets $\S$

(Mean values with their standard errors for the change in uptake, compared with the corresponding basal levels, due to $\mathrm{GH}$, for five determinations/group)

\begin{tabular}{|c|c|c|c|c|c|c|}
\hline & \multicolumn{2}{|c|}{ Control } & \multicolumn{2}{|c|}{ LP } & \multicolumn{2}{|c|}{ PF } \\
\hline & Mean & $\mathrm{SE}$ & Mean & $\mathbf{S E}$ & Mean & $\mathrm{SE}$ \\
\hline Leucine & $-7 \cdot 2$ & $9 \cdot 7$ & $-9 \cdot 8$ & $10 \cdot 2$ & $+60 \cdot x$ & I $8 \cdot 6 * \dagger$ \\
\hline Valine & -0.6 & $6 \cdot 7$ & $+6 \cdot 2$ & $5 \cdot I$ & $+28 \cdot 5$ & $7 \cdot 3 * \dagger$ \\
\hline Arginine & $+2 \cdot 5$ & $6 \cdot 4$ & $+2 \cdot 6$ & $I \cdot 2$ & $+55 \cdot 7$ & $8 \cdot 1 * *+\dagger$ \\
\hline Lysine & $+2 \cdot 8$ & $2 \cdot 3$ & +2.7 & 3.9 & $+33 \cdot 2$ & $5 \cdot 0^{* * * * \dagger \dagger}$ \\
\hline Histidine & -0.8 & 2.9 & $-2 \cdot 8$ & 6.0 & +16.0 & $3 \cdot 7^{* *}+1+\uparrow$ \\
\hline
\end{tabular}

Statistical significance of difference from control value: $* P<0.05$, ** $P<0.01, * * *<0.001$.

Statistical significance of effect of $\mathrm{GH}: \dagger P<0.05,+\dagger P<0.01,+\dagger+P<0.001$.

$\ddagger$ For details of incubation procedure, see p. 2 .

$\S$ For details of diets, see p. 2.

or the PF group. In the LP group, the basal net uptake of valine, arginine and lysine was reduced whereas in the PF group there was an increased basal net uptake of valine, lysine and histidine (Table 2).

In the presence of GH there was no significant change in the net uptake of any of the five amino acids studied in either of the groups given diets containing protein (control and LP). However, in the PF group, GH stimulated the uptake of all five amino acids (Table 3), an effect which was blocked completely by cycloheximide (Table 4) and was therefore dependent on de novo protein synthesis.

There was a significant reduction in the basal rate of incorporation into protein of all five amino acids in muscle from LP rabbits. In the PF group on the other hand, only leucine, valine and arginine incorporation was reduced in the absence of added hormone (Table 5$)$. In the presence of $\mathrm{GH}(0.5 \mu \mathrm{g} / \mathrm{ml})$ there was a significant increase in the rate of incorporation of all five amino acids in all dietary groups (Table 6). However, the magnitude of the responses was influenced by diet. The increment in 
Table 4. Effect of cycloheximide $(4 \mu g / m l)$ on the stimulation by growth hormone $(G H)$ $(0.5 \mu \mathrm{g} / \mathrm{ml}$ ) of the net uptake of amino acids (nmol/h per $\mathrm{g}$ fresh tissue) by diaphragm muscle* from intact rabbits fed for $5 d$ on a protein-free diet $\uparrow$

(Mean values with their standard errors for five determinations/group)

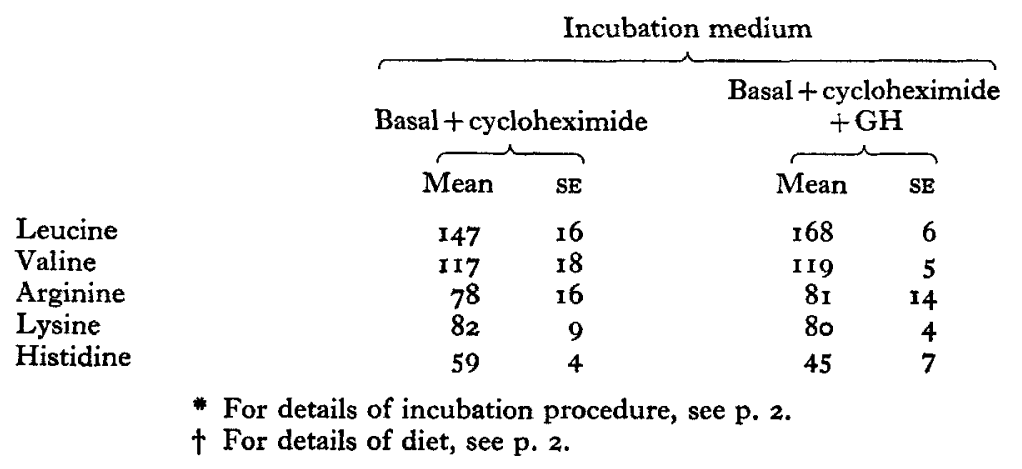

Table 5. Basal incorporation of amino acid into protein (nmol/h per $g$ fresh muscle) by diaphragm muscle $\uparrow$ from intact rabbits fed for 5 d on low-protein $(L P)$, protein-free $(P F)$ or control diets $\ddagger$

(Mean values with their standard errors for five determinations/group)

\begin{tabular}{|c|c|c|c|c|c|c|}
\hline & \multicolumn{2}{|c|}{ Control } & \multicolumn{2}{|c|}{ LP } & \multicolumn{2}{|c|}{ PF } \\
\hline & Mean & SE & Mean & sE & Mean & SE \\
\hline Leucine & $53 \cdot 2$ & $5 \cdot 2$ & 16.7 & $1 \cdot 7 * * *$ & 20.9 & $0.9^{* * *}$ \\
\hline Valine & $2.3 \cdot 8$ & $1 \cdot 9$ & $9 \cdot 2$ & $I \cdot I * * *$ & I 3.6 & $1 \cdot 6 * *$ \\
\hline Arginine & $38 \cdot 0$ & $40^{\circ}$ & $12 \cdot 3$ & $I \cdot 3^{* * * *}$ & 14.1 & $1 \cdot 3 * *$ \\
\hline Lysine & $17 \cdot 1$ & $3 \cdot 2$ & $7 \cdot 8$ & $0.9^{*}$ & $17 \cdot 1$ & $2 \cdot 1$ \\
\hline Histidine & $14 \cdot 1$ & $2 \cdot 6$ & $6 \cdot 6$ & $0.7^{*}$ & 10.6 & $I .0$ \\
\hline
\end{tabular}

Statistical significance of difference from control value: $* P<0.05, * * P<0.01, * * P<0.001$.

+ For details of incubation procedure, see p. 2.

$\mp$ For details of diets, see p. 2.

amino acid incorporation due to GH was less in muscle from the LP group than in muscle from control animals for all of the amino acids studied. In the PF group on the other hand, only the incorporation of valine and lysine was significantly reduced, but it should be noted that in the PF group, GH stimulated the net uptake of all amino acids and this in itself would favour the movement of labelled amino acid into protein, thus tending to mask a reduction in the effectiveness of GH in the PF group. In order to compare the GH effect on amino acid incorporation while taking account of the different effects of $\mathrm{GH}$ on net amino acid uptake in different dietary groups, the results have been expressed as the percentage of the net uptake of labelled amino acid which is incorporated into protein (percentage incorporation). In the control group, GH increased the percentage incorporation of all the amino acids studied. In the PF group, on the other hand, GH had no effect on the percentage incorporation, thus confirming a reduced protein-synthetic action of the hormone in this group. In 
Table 6. Effect of growth hormone $(G H)(0.5 \mu g / m l)$ on the incorporation (relative to basal incorporation) of amino acid into protein (nmol/h per $\mathrm{g}$ fresh muscle) by diaphragm muscle $\ddagger$ from intact rabbits fed for 5 d on low-protein $(L P)$, protein-free $(P F)$ or control $\operatorname{diets\S }$

(Mean values with their standard errors for the change in incorporation, compared with the corresponding basal level, due to $\mathrm{GH}$, for five determinations/group)

\begin{tabular}{|c|c|c|c|c|c|c|}
\hline & \multicolumn{2}{|c|}{ Control } & \multicolumn{2}{|c|}{ LP } & \multicolumn{2}{|c|}{ PF } \\
\hline & Mean & $\mathrm{SE}$ & Mean & SE & Mean & $\mathrm{SE}$ \\
\hline Leucine & $+15^{\circ} 4$ & o.9ttt & +9.0 & $2 \cdot 3^{*} \dagger$ & $+r_{5} \cdot 0$ & $5.2 \dagger$ \\
\hline Valine & $+17 \cdot 6$ & $2 \cdot 4+t$ & $+2 \cdot 5$ & $0.6^{* * *}+$ & +6.6 & $1 \cdot 5^{* *+}+$ \\
\hline Arginine & +110 & $I \cdot 8+\dagger$ & +3.5 & I. O***† & $+8 \cdot 4$ & $x \cdot 5+t$ \\
\hline Lysine & +12.6 & $2.5 t t$ & +20 & $0.6^{* * 1}$ & +3.7 & $0.8 * * 1$ \\
\hline Histidine & $+5^{\circ} 0$ & $I .4 T$ & $+I \cdot 9$ & $0.7 \dagger$ & +40 & $0.8+t$ \\
\hline
\end{tabular}

Statistical significance of difference from control value: ${ }^{*} P<0.05, * * P<0.01,{ }^{* *} P<0.001$.

Statistical significance of effect of GH: $+P<0.05,+\dagger P<0.01,+\dagger+P<0.00 \mathrm{r}$.

$\ddagger$ For details of incubation procedure, see p. 2.

$\S$ For details of diets, see p. 2.

Table 7. The amount of labelled amino acid taken up which is incorporated into protein (\% incorporation) by diaphragm muscle $\rfloor$ from intact rabbits fed for $5 d$ on low-protein $(L P)$, protein-free $(P F)$ or control diets $\S$

(Mean values with their standard errors for five determinations/group)

\begin{tabular}{|c|c|c|c|c|c|c|c|}
\hline & \multirow{2}{*}{$\begin{array}{l}\text { Incubation } \\
\text { medium }\end{array}$} & \multicolumn{2}{|c|}{ Control } & \multicolumn{2}{|c|}{ LP } & \multicolumn{2}{|c|}{$\mathrm{PF}$} \\
\hline & & Mean & $\mathrm{SE}$ & Mean & $\mathrm{SE}$ & Mean & SE \\
\hline Leucine & $\begin{array}{l}\text { Basal } \\
+ \text { GH }\end{array}$ & $\begin{array}{l}39 \cdot 0 \\
57 \cdot 3\end{array}$ & $\begin{array}{l}5 \cdot 1 \\
3 \cdot 9+t\end{array}$ & $\begin{array}{l}14 \cdot 6 \\
24 \cdot 7\end{array}$ & $\begin{array}{l}1 \cdot 7^{* * *} \\
4 \cdot 9^{* * * *}\end{array}$ & $\begin{array}{l}17.6 \\
18.8\end{array}$ & $\begin{array}{l}2 \cdot 3^{* *} \\
3 \cdot 5^{* * * *}\end{array}$ \\
\hline Valine & $\begin{array}{l}\text { Basal } \\
+\mathrm{GH}\end{array}$ & $\begin{array}{l}32 \cdot 5 \\
53.5\end{array}$ & $\begin{array}{l}3 \cdot 4 \\
5 \cdot 1+t+\end{array}$ & $\begin{array}{l}x 8 \cdot 7 \\
22 \cdot 5\end{array}$ & $\begin{array}{l}2 \cdot 3^{* * *} \\
x \cdot 9^{* *}\end{array}$ & $\begin{array}{l}16 \cdot 9 \\
17 \cdot 2\end{array}$ & $\begin{array}{l}\mathbf{I} \cdot 7^{* * *} \\
\mathbf{I} \cdot 8^{* * * *}\end{array}$ \\
\hline Arginine & $\begin{array}{l}\text { Basal } \\
+\mathrm{GH}\end{array}$ & $\begin{array}{l}35 \cdot 4 \\
52 \cdot 3\end{array}$ & $\begin{array}{l}4 \cdot 9 \\
5 \cdot 1 \dagger\end{array}$ & $\begin{array}{l}18.7 \\
24.3\end{array}$ & $\begin{array}{l}2 \cdot 4^{* *} \\
3 \cdot 2 * * *\end{array}$ & $\begin{array}{l}22 \cdot 1 \\
18 \cdot 8\end{array}$ & $\begin{array}{l}3 \cdot 8 * \\
3 \cdot 2^{* * * *}\end{array}$ \\
\hline Lysine & $\begin{array}{l}\text { Basal } \\
+ \text { GH }\end{array}$ & $\begin{array}{l}36 \cdot 4 \\
53 \cdot 5\end{array}$ & $\begin{array}{l}4.4 \\
3.5 \dagger\end{array}$ & $\begin{array}{l}21 \cdot I \\
27 \cdot 8\end{array}$ & $\begin{array}{l}3 \cdot 4^{* * *} \\
3 \cdot 4^{* * * *}\end{array}$ & $\begin{array}{l}22 \cdot 2 \\
2 \mathrm{I} \cdot 2\end{array}$ & $\begin{array}{l}3 \cdot 7^{*} \\
3 \cdot 8 * * *\end{array}$ \\
\hline Histidine & $\begin{array}{l}\text { Basal } \\
+\mathrm{GH}\end{array}$ & $\begin{array}{l}33 \cdot 3 \\
46 \cdot 3\end{array}$ & $\begin{array}{l}5 \cdot 4 \\
2 \cdot 7 \dagger\end{array}$ & $\begin{array}{l}2 I \cdot 8 \\
34 \cdot 4\end{array}$ & $\begin{array}{l}3 \cdot 2 \\
3 \cdot 6 \dagger\end{array}$ & $\begin{array}{l}20.9 \\
22.4\end{array}$ & $\begin{array}{l}4.2 \\
4.4\end{array}$ \\
\hline
\end{tabular}

$\mathrm{GH}$, growth hormone $(0.5 \mu \mathrm{g} / \mathrm{ml})$.

Statistical significance of difference from control value: ${ }^{*} P<0.05$, ${ }^{*} P<0.01, * * * P<0.001$.

Statistical significance of effect of $\mathrm{GH}:+P<0.05,+\uparrow P<0.01,+\dagger \dagger P<0.001$.

$\ddagger$ For details of incubation procedure, see p. 2 .

$\S$ For details of diets, see p. 2 .

the LP group, the effect of GH on the percentage incorporation was also reduced substantially, but less severely than in muscle from PF animals (Table 7 ).

There were also differences between dietary groups in the tissue:medium isotope distribution ratio $(T: M)$. The basal value for $T: M$ was lower in the LP group than in the control group for all amino acids except histidine, and in the PF group values were not different from control values for all amino acids except histidine, for which the $T: M$ ratio was increased ('Table 8). The $T: M$ ratio was significantly reduced by GH in muscle from control animals, reflecting the stimulation of amino acid 
Table 8. Tissue:medium isotope distribution ratio for diaphragm muscle $\nmid$ from intact rabbits fed for $5 d$ on low-protein $(L P)$, protein-free $(P F)$ or control diets $\ddagger$

(Mean values with their standard errors for five determinations/group; results are disintegrations/min per $\mathrm{ml}$ intracellular water

\begin{tabular}{|c|c|c|c|c|c|c|}
\hline & \multicolumn{2}{|c|}{ Control } & \multicolumn{2}{|c|}{ LP } & \multicolumn{2}{|c|}{ PF } \\
\hline & Mean & SE & Mean & SE & Mean & SE \\
\hline Leucine & $2 \cdot 29$ & 0.28 & $1 \cdot 5^{8}$ & 0.20 & $2 \cdot 12$ & 0.34 \\
\hline Valine & $I \cdot 43$ & 0.14 & 0.94 & $0.06 *$ & 2.02 & 0.36 \\
\hline Arginine & $I \cdot 3 I$ & 0.06 & 0.88 & $0.10^{*}$ & $1 \cdot 34$ & 0.30 \\
\hline Lysine & $I \cdot 25$ & 0.14 & 0.55 & $0.03 * *$ & $I \cdot 45$ & 0.22 \\
\hline Histidine & $2 \cdot 3 I$ & 0.28 & $2 \cdot 22$ & 0.24 & $4 \cdot 60$ & $0.56^{* *}$ \\
\hline
\end{tabular}

Statistical significance of difference from control value: ${ }^{*} P<0.05,{ }^{* *} P<0.01$.

+ For details of incubation procedure, see p. 2.

$\ddagger$ For details of diets, see p. 2.

Table 9. Effect of growth hormone $(G H)(0.5 \mu \mathrm{g} / \mathrm{ml})$ on the tissue:medium isotope distribution ratio (relative to basal value) for diaphragm muscle $\ddagger$ from intact rabbits fed for $5 d$ on low-protein $(L P)$, protein-free $(P F)$ or control diets $\S$

(Mean values with their standard errors for the change in the isotope distribution ratio, compared with the corresponding basal level, due to $\mathrm{GH}$, for five determinations/group; results are expressed as : $\frac{\text { disintegrations } / \mathrm{min} \text { per } \mathrm{ml} \text { intracellular water }}{\text { disintegrations } / \mathrm{min} \text { per } \mathrm{ml} \text { medium }}$ )

\begin{tabular}{|c|c|c|c|c|c|c|}
\hline & \multicolumn{2}{|c|}{ Control } & \multicolumn{2}{|c|}{ LP } & \multicolumn{2}{|c|}{ PF } \\
\hline & Mean & SE & Mean & $\mathrm{SE}$ & Mean & $\mathbf{S E}$ \\
\hline Leucine & -0.71 & $0.194 t$ & -0.33 & 0.10 & +0.73 & $0.15^{* * * *+\dagger}$ \\
\hline Valine & -0.52 & $0.15 \dagger$ & +0.05 & $0.10^{*}$ & $+1 \cdot 31$ & $0.50^{* * *}$ \\
\hline Arginine & -0.32 & $0.15 \dagger$ & -0.17 & 0.17 & $+0.6_{1}$ & $0.13^{* * \dagger}$ \\
\hline Lysine & -0.52 & o.rott & -0.01 & $0.04^{* * *}$ & +0.23 & $0.05^{* * * 1}$ \\
\hline Histidine & -0.48 & o.rott & -0.20 & 0.21 & +0.62 & $0.17^{*}$ \\
\hline
\end{tabular}

Statistical significance of difference from control value: * $P<0.05$, ** $P<0.01, * * * P<0.00 \mathrm{r}$.

Statistical significance of effect of $\mathrm{GH}:+P<0.05,+1 P<0.01$.

$\mp$ For details of incubation procedure, see p. 2.

$\S$ For details of diets, see p. 2.

incorporation with, at the same time, no change in the net amino acid uptake. In the LP group, GH had a small effect on amino acid incorporation, and no effect on the net uptake of amino acids, and as a result there were no significant changes in $T: M$ due to $\mathrm{GH}$ in this group. In the PF group, GH stimulated both amino acid incorporation and the net uptake of amino acids. The effect of GH on the net uptake of amino acids was proportionally greater than its effect on amino acid incorporation, and as a result $\mathrm{GH}$ produced a significant increase in the $\mathrm{T}: \mathrm{M}$ ratio for all amino acids to a level significantly higher than that found in muscle from control animals (Table 9). A similar effect is found in muscle from control rabbits incubated in the presence of insulin (Reeds et al. 1971) and in muscle from hypophysectomized rats incubated in the presence of GH (Kostyo, 1968). Because the muscle from PF animals produced the type of response to GH found in tissues from hypophysectomized animals, i.e. an 
increase in both amino acid incorporation and in the net amino acid uptake, the level of $\mathrm{GH}$ in the plasma was measured in five animals from each of the three dietary groups just before they were killed for use in the in vitro incubation studies. In plasma from control and LP animals, the circulating GH levels (determined by radioimmunoassay using the procedure described by Reeds (1972)) were similar, but in the PF group, far from being decreased, the plasma GH level was significantly increased. (Plasma GH (ng/ml): control $5 \cdot 2 \pm \mathrm{I} \cdot \mathrm{I}$, LP $4 \cdot 7 \pm 0 \cdot 9, \mathrm{PF} 9 \cdot 7 \pm \mathrm{I} \cdot 6$. The statistical significance of the difference between the PF group and both the control and LP group was $P<0.05$.) Thus the similarity in the type of response found in rabbits given the PF diet and that of hypophysectomized animals was not due to a reduction in plasma $\mathrm{GH}$ levels.

\section{DISCUSSION}

The concept that GH stimulates directly both amino acid uptake and amino acid incorporation is widely accepted on the basis of experiments with muscle in vitro from hypophysectomized rats, and from in vivo studies. We have challenged this concept previously on the basis of results which indicate that $\mathrm{GH}$ can stimulate amino acid incorporation in vitro in muscle from non-hypophysectomized animals without having any effect on amino acid uptake (Reeds et al. 1971). A similar finding has been made in liver, in vitro, by Clemens \& Korner (1970), and the same interpretation is possible from early findings of Kostyo ( 1964$)$, who reported that inhibition of amino acid uptake obtained by incubating muscle from hypophysectomized rats in a sodium-free medium did not prevent the GH stimulation of protein synthesis.

In this paper we have described experiments, the results of which suggest that giving a protein-free diet for $5 \mathrm{~d}$ alters the cellular response to $\mathrm{GH}$ in vitro in muscle from intact animals. In this tissue, $\mathrm{GH}$ has a similar effect to that found in muscle from hypophysectomized animals, i.e. stimulation of amino acid uptake and amino acid incorporation. Thus the interpretation of 'uptake' results from experiments using tissues from hypophysectomized animals should be regarded with caution when extrapolating back to the whole animal. Our findings suggest that the uptake effect only occurs when cellular metabolism has been altered, for example, by hypophysectomy or by protein deficiency, and that normally the action of $\mathrm{GH}$, per se, is specifically on amino acid incorporation into protein. That does not mean, however, that the in vivo finding that GH stimulates the movement of amino acid into the muscle need be regarded as erroneous. Results of recent studies on the somatomedins would allow the interpretation that whereas $\mathrm{GH}$ itself has a specific action on the incorporation process, it also results in the production of a material from the liver which has insulin-like activity and may stimulate amino acid uptake (Uthne, 1973). This idea could be represented by the following scheme (in the normal, intact animal):

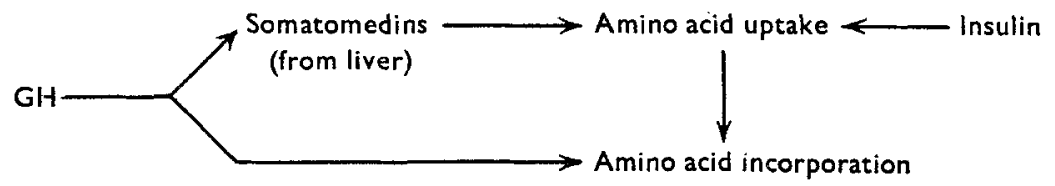


In addition to altering the nature of the response of muscle to $\mathrm{GH}$, the PF diet also altered the magnitude of the response. Thus the effect of GH on the incorporation of valine and lysine into protein was significantly reduced although the net uptake of these amino acids was increased both at the basal level and in the presence of GH. 'The basal and GH-stimulated uptake of histidine was also significantly increased, but although the effect of $\mathrm{GH}$ on amino acid incorporation was less than that of the control group, the difference was not statistically significant. The basal net uptake of leucine was not significantly changed in muscle from the PF rabbits, but the stimulatory effect of GH on net uptake was substantial, GH producing an increase in net uptake of $60 \mathrm{nmol} / \mathrm{h}$ per $\mathrm{g}$ muscle. Although this big increase was obtained in the influx of labelled amino acid into the cell, which in itself would increase the incorporation of amino acid into protein, the level of amino acid incorporation found in the $\mathrm{PF}$ group in the presence of $\mathrm{GH}$ was not greater than that in control tissue, suggesting again a reduced effect of $\mathrm{GH}$ on the incorporation process. Similarly in the muscle from LP animals, in which the net uptake was not stimulated by GH, the tissue responsiveness to $\mathrm{GH}$ as measured by amino acid incorporation into protein was significantly reduced for all five amino acids studied. Therefore, it is possible to reconcile results of our experiments with in vitro findings in muscle from hypophysectomized animals, and with in vivo results. It can be postulated that GH has an effect on muscle protein synthesis, by influencing ribosomal activity, and simultaneously favours the movement of amino acids into the cells as a result of the production of somatomedins from the liver under the influence of GH. In hypophysectomized animals, in severe short-term protein deficiency, and in moderate longterm protein deficiency (Allen, Munday \& Turner, 1974a,b), cellular function is altered so that GH itself is able to have an effect in vitro on the uptake process as a consequence of its action on protein synthesis. An important outstanding question is the mechanism by which this altered tissue response to $\mathrm{GH}$ in vitro occurs.

Having found that $\mathrm{GH}$ can stimulate amino acid incorporation without the need for a simultaneous increase in amino acid uptake, in which respect it differs from insulin in its mode of action in the adult, it is appropriate to examine the role of $\mathrm{GH}$ in the day-to-day regulation of metabolism. After a meal, insulin secretion is stimulated but GH secretion is suppressed. In the 'between-meals' situation, however, the converse would tend to be true. With increasing GH levels, the lipolytic action of the hormone results in a greater utilization of lipid for energy metabolism and a consequent conservation of the carbohydrates in the body (Russell, r95 r). In the shortterm fast it is equally important to sustain essential protein synthesis and, because GH can stimulate protein synthesis in the absence of any stimulation of amino acid uptake, it could be postulated that GH could protect the body from adverse effects of a short-term fast both by conserving carbohydrate, which in turn prevents excessive amino acid catabolism, and also by sustaining cellular protein synthesis in the presence of ever-decreasing levels of substrate amino acids. In protein-energy malnutrition the supply of amino acids to the muscle would also be reduced, and in this situation one can again postulate the importance of $\mathrm{GH}$ in sustaining essential protein synthesis. The reduced tissue response to $\mathrm{GH}$ in protein-deficient groups in our experiments 
could be regarded as an adaptation to minimize amino acid utilization. However, it is interesting that in the protein-free rabbits, in less severe long-term protein deficiency in rabbits, and in most forms of human malnutrition, the circulating $\mathrm{GH}$ levels are increased, and this would tend to compensate for a reduction in the protein-synthetic response of the tissue to the hormone. In the most severe deficiency state, i.e. in the rabbits given the $\mathrm{PF}$ diet, the nature of the tissue response to $\mathrm{GH}$ changed so that there was an active uptake of amino acid in the presence of the hormone, i.e. GH had an insulin-like effect. We have obtained a similar response in muscle in vitro from intact rabbits subjected to a moderately severe protein deficiency, achieved without there being a concomitant reduction in energy uptake, for 18 weeks from weaning (Allen et al. 1974a), and in the newborn offspring of rabbits subjected to a similar dietary situation during gestation (Allen et al. 1974b). It would be interesting to know the responsiveness of muscle from malnourished infants to $\mathrm{GH}$ in vitro, to determine whether they had also made this type of adaptation to the adverse nutritional environment, an adaptation which would favour the movement of amino acid into muscle proteins and the most efficient utilization of the limited dietary supply of amino acids.

\section{REFERENCES}

Allen, K. A., Munday, K. A. \& Turner, M. R. (1974a). Proc. Nutr. Soc. 33, I I 2 A.

Allen, K. A., Munday, K. A. \& Turner, M. R. (1974b). Proc. Nutr. Soc. 33, Ir 3 A.

Beas, F., Contreras, I., Maccioni, A. \& Arenas, S. (1971). Br. F. Nutr. 16, 169.

Clemens, M. J. \& Korner, A. (1970). Biochem. F. I19, 629.

Hjalmarson, A. (1968). Acta endocr., Copenh. 57, Suppl. 126, 37.

Jones, J. H. \& Foster, C. (1942). F. Nutr. 24, 245.

Knobil, E. (1 966). Physiologist, Wash. 9, 25.

Kostyo, J. L. (1964). Endocrinology 75, I1 3 .

Kostyo, J. L. (1968). Ann. N.Y. Acad. Sci. 148, 389.

Kostyo, J. L. \& Knobil, E. (1959). Endocrinology 65, 395.

Kostyo, J. L. \& Rillema, J. A. (1971). Endocrinology 88, ro54.

Manchester, K. L. \& Young, F. G. (1961). Vitam Horm. 19, 95.

Milner, R. D. G. (197 I). Pediat. Res. 5, 33.

Pimstone, B. L., Barbezat, G., Hansen, J. D. L. \& Murray, P. (1968). Am. Y. clin. Nutr. 21, 482.

Reeds, P. J. (1972). Effects of insulin and growth hormone on amino acid utilization in muscle. PhD Thesis, University of Southampton.

Reeds, P. J., Munday, K. A. \& Turner, M. R. (197x). Biochem. J. 125, 515.

Russell, J. A. (r95I). Endocrinology 49, 99.

Turner, M. R. (1972). Proc. Nutr. Soc. 3I, 205.

Turner, M. R., Allen, K. A. \& Munday, K. A. (1974). Proc. Nutr. Sac. 33, 56A.

Turner, M. R., Reeds, P. J. \& Munday, K. A. (197I). Excerpta med. int. Congr. ser. no. 236: Proc. 2 nd int. Symp. Growth Hormone, p. 40.

Uthne, K. (1973). Acta endocr., Copenh. 73, Suppl. 175. 